\title{
PENGARUH CIRCUIT TRAINING CORE STABILITY DYNAMIC TERHADAP KESEIMBANGAN DAN KEKUATAN OTOT PERUT DI SSB PSBK JUNIOR
}

\author{
Indra Gunawan Pratama, M.Pd. \\ Universitas Nahdlatul Ulama Blitar \\ indragunawanpratama21@gmail.com
}

\begin{tabular}{l}
\hline Tersedia Online di \\
\hline http://www.jurnal.unublitar.ac.id/ \\
index.php/briliant \\
\hline
\end{tabular}

\section{Sejarah Artikel}

Diterima pada 12 Desember 2018

Disetuji pada 25 Januari 2019

Dipublikasikan pada 20 Februari

2019 Hal. 27-34

\begin{tabular}{l}
\hline Kata Kunci: \\
\hline Circuit Training, Core Stabiliy \\
Dynamic, Keseimbangan, \\
Kekuatan Otot Perut \\
\hline DOI: \\
\hline http://dx.doi.org/10.28926/briliant \\
.v3i3.261 \\
\hline
\end{tabular}

Abstrak: Latihan kondisi fisik khususnya pada keseimbangan dan kekuatan otot perut sangat dibutuhkan pada setiap cabang olahraga untuk memperoleh kemampuan atau kinerja yang optimal. Keseimbangan dan kekuatan otot perut perlu dilatih dengan terukur dengan latihan circuit training core stability dynamic. Latihan core stability telah menjadi bagian yang tidak terpisahkan dari latihan untuk semua atlet berprestasi dengan tujuan meningkatkan penampilan gerak dan kestabilan tubuh untuk factor resiko terjadinya cidera. Tujuan dari penelitian ini melihat seberapa besar pengaruh circuit training core stability dynamic terhadap keseimbangan dan kekuatan otot perut. Sasaran penelitian ini adalah SSB PSBK Junior. Jenis penelitian yang digunakan dalam penelitian ini adalah kuantitatif dengan eksperimen semu. Instrumen pengambilan data dilakukan dengan tes keseimbangan (stork stand) dan Kekuatan otot perut (Sit-Up) pada saat pretest dan posttest. Adanya pengaruh yang signifikan pada circuit training core stability dynamic terhadap keseimbangan dan kekuatan otot perut di SSB PSBK Junior Kota Blitar dengan peningkatan sebesar $49,12 \%$ untuk keseimbangan dan 30,16\% untuk peningkatan kekuatan otot perut.

\section{PENDAHULUAN}

Perkembangan olahraga di Indonesia masih banyak yang harus di tingkatkan dalam prestasi olahraga, Prestasi olahraga di Indonesia mengalami percepatan yang lebih lamban dibandingkan dengan Negara-negara lain seperti Cina, Jepang, Korea, dan bahkan Thailand. Dalam era modern, khususnya pada olahraga merupakan suatu kemajuan ilmu pengetahuan dan teknologi (IPTEK) yang sangat pesat dalam berbagai kehidupan manusia termasuk olahraga. Manusia yang bugar dan sehat tentu memiliki kinerja yang lebih baik dibandingkan dengan manusia yang kurang bugar atau sehat, olahraga merupakan pilihan yang tepat untuk memenuhi kehidupan yang lebih berarti. Olahraga merupakan salah satu aktifitas fisik yang komplek dan selalu mengalami suatu perkembangan melalui berbagai macam bentuk latihan. Dalam dekade terakhir ada beberapa negara telah mempromosikan peningkatan kebugaran fisik di antaranya pada generasi muda dengan memakai cara yang berbeda [5]. Setiap manusia membutuhkan olahraga dan mempunyai suatu tujuan penting untuk kebugaran dan prestasi yang akan dicapai. Jika melakukan suatu pencapaian olahraga, maka harus meningkatkan taraf kehidupan yang lebih baik antara waktu istirahat, waktu kerja, serta nutrisi untuk menjaga kestabilan tubuh agar tetap optimal dan juga memiliki kegiatan 
aktifitas yang rutin yang terprogram dengan baik, sehingga dapat menghasilkan kualitas tujuan menjadi tercapai.

Latihan sirkuit (circuit training) yang merupakan latihan countinue di mana latihan yang digabungkan dengan latihan kekuatan dan latihan aerobic, yang juga menggabungkan manfaat dari latihan kekuatan fisik [4]. Circuit training memiliki beberapa kelompok olahraga atau pos yang sudah ada di area dan diselesaikan dengan cepat. Menurut Antonio [2] menyatakan bahwa latihan sirkuit (circuit training) intensitas tinggi lebih efektif dalam meningkatkan pada kebugaran kardiorespirasi, kekuatan otot, dan komposisi tubuh.

Beberapa model latihan yang dapat diterapkan pada latihan sirkuit (circuit training) salah satunya dengan menggunakan model latihan core stability dinamic. core stability semakin dianjurkan dalam program pengkondisian olahraga. Menurut Johnson [12] Core stability merupakan kemampuan untuk mengontrol posisi dan pergerakan dari bagian sentral tubuh dan latihan core stability menargetkan otot-otot dalam perut yang terhubung ke tulang belakang, panggul dan bahu, yang membantu dalam pemeliharaan postur yang baik dan memberikan dasar gerakan untuk semua lengan dan kaki. Menurut Gambell [6] mengemukakan wilayah lumbopelvic pasti akan menjadi penghubung penting dalam rantai kinetik (menggabungkan sendi dari tubuh bagian bawah dan dorongan ke tubuh bagian atas) terlibat dalam semua gerakan olahraga.

Berdasarkan penjelasan tentang core stability di atas, maka peneliti memutuskan untuk memilih komponen fisik yang sesuai dengan latihan sirkuit core stability tentang keseimbangan dan kekuatan otot perut. [9] Keseimbangan merupakan kondisi ketidakstabilan yang lebih tinggi untuk meningkatkan kontrol postural dan meningkatkan aktivitas otot inti untuk menstabilkan tubuh. Menurut Struhar [8] Sistem kontrol postural menggunakan proses yang kompleks yang melibatkan komponen sensorik dan motorik untuk menjaga keseimbangan postural yang membutuhkan informasi sensorimotor dengan sistem saraf pusat dan pelaksanaan respon muskuloskeletal yang tepat. Selain keseimbangan ada beberapa komponen fisik lainnya yang dapat menunjang kegiatan olahraga salah satunya adalah kekuatan. [3] menyatakan kekuatan sebagai kerja maksimal (maximal force) atau torque (rotational force) yang dihasilkan otot atau sekelompok otot. Oleh karena itu kekuatan pada tubuh manuasia dapat berargumentasi bahwa kekuatan otot optimal akan menambah performa bagi atlet.

\section{METODE}

\section{Jenis dan Desain Penelitian}

Metode penelitian yang digunakan adalah metode eksperimen karena mencari peningkatan dari variabel yang mengenai, Pengaruh circuit training core stability dynamic. Metode eksperimen adalah metode penelitian yang digunakan untuk mencari pengaruh perlakuan tertentu terhadap yang lain dalam kondisi yang terkendalikan [13]. Pendekatan dalam penelitian ini adalah penelitian eksperimen semu (quasi exsperiment) dengan rancangan penelitian menggunakan Randomonly design [11]. Rancangan penelitian tersebut dapat digambarkan sebagai berikut:

Gambar 3.1 Desain Penelitian [10]. 


\begin{tabular}{|l|c|c|c|}
\hline Random Sampling & Pretest & Treatment & Post test \\
\hline Kelompok Core Stablity Dynamic & $\mathrm{T}$ & $\mathrm{X}$ & $\mathrm{T}$ \\
\hline Kelompok Kontrol & $\mathrm{T}$ & - & $\mathrm{T}$ \\
\hline
\end{tabular}

\section{Instrumen Penelitian}

Jenis tes yang digunakan untuk mengukur keseimbangan stork stand dan otot perut sit ups. Dalam buku metode penelitian dijelaskan bahwa instrumen adalah suatu alat yang digunakan mengukur fenomena alam maupun sosial yang diamati [13]. Adapun standar operasional prosedur (SOP) tes keseimbangan (stork stand) dan kekuatan otot perut (Sit-Ups) sebagai berikut:

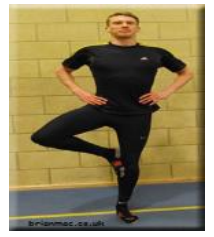

Gambar: Stork Stand Test Sumber: http://www.brianmac.co.uk/storktst.htm

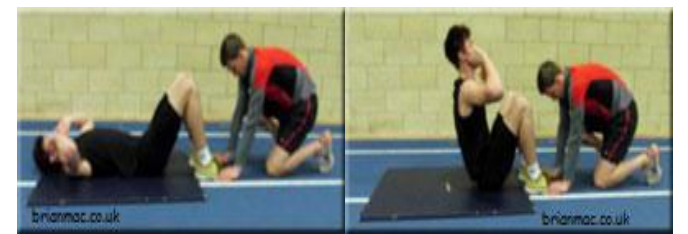

Gambar: Sit Ups Test

\section{Sumber: http://www.brianmac.co.uk/situptst.html}

\section{Teknik Analisis Data}

Uji Normalitas Data

Menentukan normal tidaknya distribusi data adalah membandingkan taraf signifikansi perhitungan data dengan taraf 5\%. Jika taraf signifikansi dalam uji statistik lebih besar dari 0.05 maka dinyatakan berdistribusi normal.

Uji Homogenitas

penelitian ini digunakan lavene's test. Apabila nilai statistik lavene lebih besar dari 0.05 maka data memiliki varian yang homogen.

Uji Hipotesis

Untuk mengetahui perbedaan pengaruh perlakuan pada variabel terikat sebelum dan setelah perlakuan setiap kelompok penelitian digunakan paired t-test, keputusan penolakan hipotesis pada $\alpha=0,05$.

Untuk mengetahui perbedaan pengaruh perlakuan terhadap peningkatan keseimbangan dan kekuatan otot perut sebelum dan setelah perlakuan antar kelompok digunakan statistik analisis varian satu (one way anova) jalur keputusan penolakan hipotesis pada $\alpha=0,05$.

\section{HASIL}

Deskripsi data pada kelompok Core Stability Dynamic memberikan gambaran tes awal, tes akhir, rata-rata, dan standar deviasi dari masing-masing 
variabel terikat yaitu keseimbangan dan kekuatan otot perut. Perolehan data dari hasil kelompok kontrol dari varibel terikat keseimbangan dan kekuatan otot perut dapat dilihat pada tabel sebagai berikut.

Tabel 1. Perolehan Data Pre Test dan Post Test Kelompok Core Stability Dynamic

\begin{tabular}{|c|c|c|c|c|}
\hline \multirow{2}{*}{} & \multicolumn{2}{|c|}{ Keseimbangan } & \multicolumn{2}{c|}{ Kekuatan Otot Perut } \\
\cline { 2 - 5 } & Pretest & Posttest & Pretest & Posttest \\
\hline Total & 114 & 170 & 189 & 246 \\
\hline Rerata & 10.36 & 15.45 & 17.18 & 22.36 \\
\hline SD & 1,29 & 1,13 & 1,17 & 1,57 \\
\hline Peningkatan & \multicolumn{2}{|c|}{$49,12 \%$} & \multicolumn{2}{c|}{$30,16 \%$} \\
\hline
\end{tabular}

Dapat diketahui bahwa ada peningkatan sebesar $49,12 \%$ untuk keseimbangan dan 30,16\% untuk peningkatan kekuatan otot perut. Berikut hasil rerata kelompok Core Stability Dynamic yang digambarkan dalam bentuk diagram.

Grafik 1. Pretest dan Posttest dari kedua variabel terikat kelompok Core Stability Dynamic.

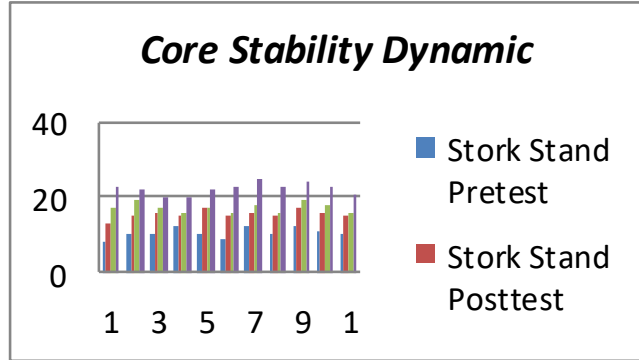

Dekripsi data pada kelompok Kontrol memberikan gambara tentang tes awal, tes akhir, rata-rata, dan standar deviasi dari masing-masing variabel terikat yaitu keseimbangan dan kekuatan otot perut. Perolehan data dari hasil kelompok kontrol dari varibel terikat keseimbangan dan kekuatan otot perut dapat dilihat pada tabel sebagai berikut.

Tabel. Perolehan Data Pre Test dan Post Test Kelompok Kontrol.

\begin{tabular}{|c|c|c|c|c|}
\hline \multirow{2}{*}{} & \multicolumn{2}{|c|}{ Keseimbangan } & \multicolumn{2}{c|}{ Kekuatan Otot Perut } \\
\cline { 2 - 5 } & Pretest & Posttest & Pretest & Posttest \\
\hline Total & 106 & 133 & 188 & 206 \\
\hline Rerata & 9.64 & 12.09 & 17.09 & 18.73 \\
\hline SD & 1,12 & 1,76 & 1,04 & 1,27 \\
\hline Peningkatan & \multicolumn{2}{|c|}{$25,47 \%$} & \multicolumn{2}{c|}{$9,57 \%$} \\
\hline
\end{tabular}

Berdasarkan pada tabel diatas dapat diketahui bahwa ada peningkatan sebesar 25,47\% untuk keseimbangan dan 9,57\% untuk peningkatan kekuatan otot perut. Dengan demikian kelompok kontrol juga memberikan dampak pada keseimbangan dan kekuatan otot perut, meskipun dengan peningkatan relative 
kecil dibandingkan dengan kelompo core stanility dynamic. Berikut hasil rerata kelompok Core Stability Dynamic yang digambarkan dalam bentuk diagram.

Grafik 2. Pretest dan Posttest dari kedua variabel terikat kelompok Core Stability Dynamic

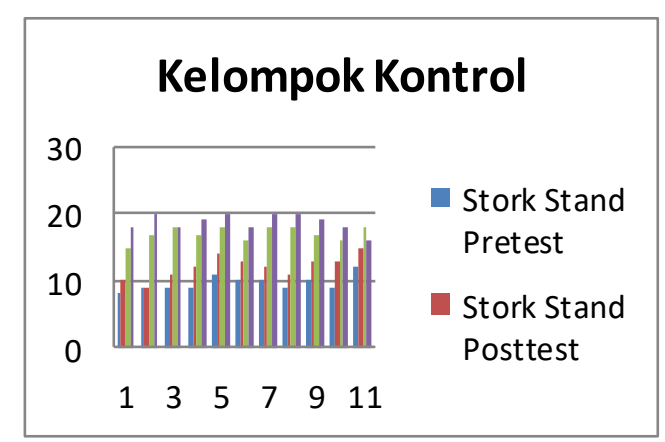

Uji Normalitas

Hasil uji normalitas diperoleh dari nilai variabel terikat (kekuatan otot perut) yang dilakukan sebelum eksperimen dengan menggunakan Kolmogorov-Smirnov Test, umtuk mengetahui adanya normalitas atau tidak. Dengan taraf signifikansi 0,05, rangkuman hasil uji normalitas populasi menggunakan Kolmogorov-Smirnov Test disajikan dalam Tabel berikut.

Tabel 2. Hasil Uji Normalitas Data Variabel Terikat

\begin{tabular}{|c|c|c|c|c|}
\hline \multirow{2}{*}{ Variabel } & \multirow{2}{*}{ Test } & Core Stability & Kontrol & \multirow{2}{*}{ Status } \\
\cline { 3 - 4 } Kekuatan Otot Perut & Sig & Sig & \\
\cline { 2 - 4 } & Pretest & 0.200 & 0.033 & Normal \\
\hline \multirow{2}{*}{ Keseimbangan } & Pretest & 0.200 & 0.200 & Normal \\
\cline { 2 - 4 } & Post Test & 0.058 & 0.058 & Normal \\
\hline
\end{tabular}

Uji Homogenitas

Uji homogenitas diperlukan untuk mengetahui kesamaan subjek dari populasi. Variabel yang harus diuji homogenitas data dalam penelitian ini adalah kekuatan otot perut. Hasil perhitungan spss versi 25.0 untuk perhitungan homogenitas data seperti pada tabel berikut.

Tabel 3 .Hasil Uji Homogenitas Data Variabel Terikat

\begin{tabular}{|l|l|l|l|l|}
\hline Varabel & Test & Sig $(\mathrm{P})$ & Ket & Status \\
\hline \multirow{2}{*}{ Kekuatan Otot Perut } & Pre test & 0.789 & $\mathrm{P}>0.05$ & Homogen \\
\cline { 2 - 5 } & Post Test & 0.656 & $\mathrm{P}>0.05$ & Homogen \\
\hline \multirow{2}{*}{ Keseimbangan } & Pre test & 0.515 & $\mathrm{P}>0.05$ & Homogen \\
\cline { 2 - 5 } & Post Test & 0.365 & $\mathrm{P}>0.05$ & Homogen \\
\hline
\end{tabular}

Berdasarkan pa tabel 5.4 dapat dilihat bahwa nilai signifikansi dari masingmasing data variabel terikat (kekuatan otot perut dan keseimbangan) menunjukkan 
taraf signifikan atau $(\mathrm{p})>.0,05$. Kesimpulan bahwa, varians pada tiap kelompok adalah sama atau homogen.

Uji Hipotesis

Tabel 5.5 Hasil Anova Core Stabililty Dyanmic (Kekutan Otot Perut)

\begin{tabular}{|l|l|l|l|l|l|}
\hline \multicolumn{7}{|c|}{ ANOVA } \\
\hline Kekuatan Otot Perut & Sum of Squares & df & Mean Square & F & Sig. \\
\hline & 8.386 & 5 & 1.677 & 1.597 & .310 \\
\hline Between Groups & 5.250 & 5 & 1.050 & & \\
\hline Within Groups & 13.636 & 10 & & & \\
\hline Total & 13.636 & & & \\
\hline
\end{tabular}

Berdasarkan pada tabel 5.5 dapat dilihat bahwa hasil yang diperoleh menggunakan aplikasi SPSS Versi 25.0 dengan hasil sig. (2-tailed) $<0,05$ maka terdapat nilai signifikansi dari masing-masing data variabel terikat (kekuatan otot perut dan keseimbangan) menunjukkan peningkatan latihan.

Tabel 4 Hasil Anova Kelompok Core Stabililty Dyanmic (Keseimbangan)

\begin{tabular}{|c|r|l|l|l|l|}
\hline \multicolumn{7}{|c|}{ ANOVA } \\
\hline Keseimbangan & Sum of Squares & df & Mean Square & F & Sig. \\
\hline Between Groups & 7.745 & 3 & 2.582 & 2.054 & .195 \\
\hline Within Groups & 8.800 & 7 & 1.257 & & \\
\hline Total & 16.545 & 10 & & & \\
\hline
\end{tabular}

Berdasarkan pada tabel 5.6 dapat dilihat bahwa hasil yang diperoleh menggunakan aplikasi SPSS Versi 25.0 dengan hasil sig. (2-tailed) $<0,05$ maka terdapat nilai signifikansi dari masing-masing data variabel terikat (kekuatan otot perut dan keseimbangan) menunjukkan peningkatan latihan.

Tabel 5 Hasil Anova Kelompok Kontrol (Keseimbangan)

\begin{tabular}{|l|l|l|l|l|l|}
\hline \multicolumn{7}{|c|}{ ANOVA } \\
\hline Keseimbangan & Sum of Squares & df & Mean Square & F & Sig. \\
\hline Between Groups & 11.879 & 6 & 1.980 & 1.697 & .317 \\
\hline Within Groups & 4.667 & 4 & 1.167 & & \\
\hline Total & 16.545 & 10 & & & \\
\hline
\end{tabular}

Berdasarkan pada tabel 5.7 dapat dilihat bahwa hasil yang diperoleh menggunakan aplikasi SPSS Versi 25.0 dengan hasil sig. (2-tailed) $<0,05$ maka terdapat nilai signifikansi dari masing- asing data variabel terikat (kekuatan otot perut dan keseimbangan) menunjukkan peningkatan latihan.

Tabel 6. Hasil Anova Kelompok Kontrol (Kuatan Otot Perut) ANOVA

Kekuatan Otot perut 


\begin{tabular}{|l|l|l|l|l|l|}
\hline & Sum of Squares & $\mathrm{df}$ & Mean Square & $\mathrm{F}$ & Sig. \\
\hline Between Groups & 5.409 & 3 & 1.803 & 2.295 & .165 \\
\hline Within Groups & 5.500 & 7 & 786 & & \\
\hline Total & 16.545 & 10 & & & \\
\hline
\end{tabular}

Berdasarkan pada tabel 5.8 dapat dilihat bahwa hasil yang diperoleh menggunakan aplikasi SPSS Versi 25.0 dengan hasil sig. (2-tailed) $<0,05$ maka terdapat nilai signifikansi dari masing-masing data variabel terikat (kekuatan otot perut dan keseimbangan) menunjukkan peningkatan latihan.

\section{SIMPULAN}

Berdasarkan hasil pengolahan data dan pembahasan, maka dapat disimpulkan bahawa: Adanya pengaruh yang signifikan pada circuit training core stability dynamic terhadap keseimbangan dan kekuatan otot perut di SSB PSBK Junior Kota Blitar dengan peningkatan sebesar 49,12\% untuk keseimbangan dan $30,16 \%$ untuk peningkatan kekuatan otot perut. latihan core stability sangat efektif dilakukan pada semua cabor olahraga yang pada umumnya meningkatkan keseimbangan dan kekuatan otot perut. Hasil pretest (kemampuan awal pemain) menunjukkan bahwa data berdistribusi normal dan homogen.

\section{PEMBAHASAN}

Pembahasan hasil penelitian ini mengacu pada data yang diperoleh dari hasil tes awal tes akhir kemudian yang analisis adalah nilai beda. Peneliti menyampaikan bahwa tujuan penelitian ini adalah untuk menganalisis circuit training core stability dynamic terhadap keseimbangan dan kekuatan otot perut. Core stability dynamic meningkatkan penampilan gerak dan kestabilan tubuh untuk factor resiko terjadinya cidera. Kelompok program circuit training core stability dynamic menunjukkan pengaruh yang signifikan terhadap keseimbangan 49,12\% dan kekuatan otot perut dengan peningkatan $30,16 \%$. Kinerja pada keseimbangan dan kekuatan otot perut kelompok circuit training core stability dynamic meningkat dari tes awal ke tes akhir.

\section{KESIMPULAN}

Mengacu pada hasil analisis data, pembahasan hasil penelitian, dan diskusi hasil peneitian dengan ini dapat di simpulkan sebagai berikut.

1. Terdapat pengaruh yang signifikan pada circuit training core stability dynamic terhadap keseimbangan dan kekuatan otot perut.

2. Hasil pretest (kemampuan awal pemain) menunjukkan bahwa data berdistribusi normal dan homogen.

\section{SARAN}

1. Untuk meningkatkan keseimbangan dan kekuatan otot perut pada subjek peneitian, dapat dilakukan dengan program circuit training core stability dynamic. Sehingga pelatih dapat dijadikan program latihan tersebut seagai acuan dalam upaya meningkatkan keseimbangan dan kekuatan otot perut

2. Perlu diadakan penelitian lebih lanjut terkait dengan program circuit training core stability dynamic, dengan menambah variasi latihan 
seperti kombinasi latihhan core stability dynamic pada sampel yang berbeda, dengan harapan memeberikan hasil yang lebih optimal.

3. Bagi trainer akan lebih kreatif menyususn program latihan sesuai dengan kemampuan subjek, serta subjek melaksanakan program latihan yang telah di siapkan oleh pelatih, sehingga tujuan dari pelatih akan tercapai.

4. Bagi peneliti agar dapat dijadikan sebagai bahan masukan maupun perbandingan, jika peneliti ingin mengangkat masalah yang sejenis.

\section{DAFTAR RUJUKAN}

Antonio Paoli, Quirico F Pacelli, Tatiana Moro, Giuseppe Marcolin, Marco Neri, Giuseppe Battaglia, Giuseppe Sergi, Francesco Bolzetta, Antonino Bianco. 2013. Effects of high-intensity circuit training, low-intensity circuit training and endurance training on blood pressure and lipoproteins in middle-aged overweight men, Paoli et al. Lipids in Health and Disease 2013, 12:131, http://www.lipidworld.com/content/12/1/131.

Bompa, and Haff,G. 2009. Theory and Methodology of Training. United States : Human Kinetics.

Comyns, Tom. 2015. Circuit Training Development Of Strength \& Conditioning. Ireland: Lucozade Sport.

Daniel Mayorga-Vega, Jesús Viciana, Armando Cocca. 2013. Effects of a Circuit Training Program on Muscular and Cardiovascular Endurance and their Maintenancein Schoolchildren, Journal of Human Kinetics volume 37/2013, 153-160.

Gambel Paul. 2010. Strength And Conditioning For Team Sports: Sport-Specific Physical Preparation For High Performance. USA: Routledge.

Gunay Yildizir and Sadettin Kirazer, 2017. Effects of core stability on junior male soccer players' balance: randomized control trial. PJSS Pamukkale Journal Of Sport Sciences, Vol 2017, 8(1), 48-62, ISSN: 1309-0356.

Ivan Struhar, Lenka Dovrtelova, Katerina Kapounkova. 2014. Efdect Of Exercise With Elastic Cord On Postural Stability In a Group Of Elite Gymnasts. Journal Of Human Sport And Exercise ISSN 1988-5202.

Johnson, Joshua. 2012. Functional Rehabilitation Of Low Back Pain With Core Stabilization Exercise: Suggestions For Exercise and Progressions in Athletes.

Maksum, Ali. 2012. Metodologi Penelitian Dalam Olahraga. Surabaya: Unesa University Press.

Ratamess, Nicholas. 2012. ACSM's Foundations Of Strength Training and Conditioning. American College Of Sport Medicine. Wolters Kluwer.

Sugiyono. 2011. Metode Penelitian Kuantitatif, Kualitatifdan $R \& D$. Penerbit Alferta, Bandung. 